\title{
Design of Solar Pond calculation and technique in Africa
}

\author{
Jerome Godwin Egbe, Ahmed Hassan Khan, Wongsakorn Wisatesajja \\ ${ }^{11}$ Civil Engineering Department/Cross River University of Technology, Nigeria) \\ ${ }^{21}$ Chemical \& Process Engineering/University of Surrey, Pakistan ${ }^{31}$ Chemical \&Process Engineering \\ Department/University of Surrey, Thailand)
}

\begin{abstract}
Extracting energy from the sun has revolutionized the global energy industry. Different literatures have been reviewed to give an appropriate theory and mathematical model for the design of solar pond in Africa.The location chosen is Cairo,Egypt due to high annual solar radiation,feasible land, and fresh water conditions and cost effective. Energy balance equations have been computed from different case studies to show the factors affecting the efficiency of the solar pond such as effect of density, temperature, solar radiation, insulation thickness and depth of different layers.Optimum conditions for the design of a solar pond have been determined such as the thickness of the upper layer should not be more than 0.3m whereas the optimum thickness of gradient zone should be1-1.5m and the storage zone should be 1-4m.The main constraints in the design of a solar pond are different heat losses.But however, different techniques have been discussed for reducing the heat losses such as black painted concrete slab and concrete walls for minimizing the bottom losses and using a polystyrene top cover for reducing evaporation losses during night, winters and autumn. This technique can be very useful for the people of Africa specially dwelling in rural areas.
\end{abstract}

Keywords: Design, Solar Pond,RenewableEnergy

\section{Introduction}

Global warming could be one of the world's most important issues in the $21^{\text {st }}$ century [13].Every year, billions of tonnes of carbon dioxide have been emitted into the global atmosphere[1].Global warming mainly occurs due to human activities such as transportation, producing electricity and in industries which involves burning fossil fuels[2], which could lead to a significant decrease in world fossil fuels reserves[3].However, renewable energy technologies have been developed and introduced as an alternative source for energy production; renewable energy technology can produce energy with zero carbon dioxide emissions, unlimited sources and benefits the economy[11].

Solar energy is one of the essential world renewable energy sources. The conversion of the energy can be operated by several techniques such as photovoltaic systems for producing electricity and solar hot water for heating water with solar energy. Solar ponds have been suggested to be simple and economical in terms of collecting and storing energy on a large scale. There are two types of solar ponds depending on the convecting behaviors and the non- convecting solar ponds [4].

The location of a non-convecting solar pond is at Cairo, Egypt $\left(30.0566^{\circ} \mathrm{N}, 31.2262^{\circ} \mathrm{E}\right)$. Based on the NASA websites, Egypt has abundant sunshine with an annual average solar irradiationabout $5.35 \mathrm{kWh} / \mathrm{m}^{2} / \mathrm{day}$ [6].

The objective of this work is to provide the appropriate theory, cost estimation, design reality, specification and calculation details such as temperature effect,radiation effect, depth effect, density effect and the produced temperature of the pond.

This report has been divided into different chapters with background in Chapter 2.An appropriate theory for this task is expanded in the chapter 3.The design and detailed mathematical model for the task is explained in chapter $3 \& 4$ respectively. Chapter 5 deals with the values of different parameters and results of different factors affecting the efficiency of the solar pond, cost estimation, and conclusion of the project are described. Finally, the number and detail of references used for the report are also listed.

In the seventies when the oil crisis occurred and also later through the eighties, much research and development was on the potential of using a solar pond as an alternative power generating. Solar ponds are controlled body of water that collects and stores solar energy.Solar ponds neither use tracking systems such as mirror, nor do they concentrate the sun's rays like other solar technologies. Ponds can be naturally occurring, however most ponds in Africa or the world at large, are man-made.

\section{Theory}

The"fig."1.Shows the salt-water solar pond, which the amount of salts dissolved in the water, has increased with depth. Therefore, the salinity and density of each layer in the pond would also be increased with depth, so it is called a salt stabilized or salinity-gradient solar pond. The layer below salinity-gradient zone is called storage zone which can be defined as saturated salt solution, and above salinity-gradient zone which the 
layer of fresh or low-salinity water, it is called the surface zone. The thickness of storage zone is normally around one or two meters, the surface zone is around 0.3 meters and the overall pond should be around two or more meters [1].

If the solar ponds have suitable gradient of salt concentration at the storage zone and clear fresh water at surface zone. Therefore, the solar energy would be absorbed and collected by the storage zone, which salt water will not rise when it has been heated due to the salt water is heavier than the fresh water on the surface zone. Then the surface zone acts as an insulating blanket and temperature at the storage zone could reach up to $90^{\circ} \mathrm{C}$ [2]. This temperature is high enough to generate a vapour cycle engine to generate the electricity.

Solar Ponds can be used for different applications. Process Heat, Solar ponds can be used for heating purposes in many ways such as Process Industries, Domestic \& Commercial Heating Systems in colder countries, Thermal Electricity desalination. Solar Ponds can play an efficient role in providing clean drinking water refrigeration

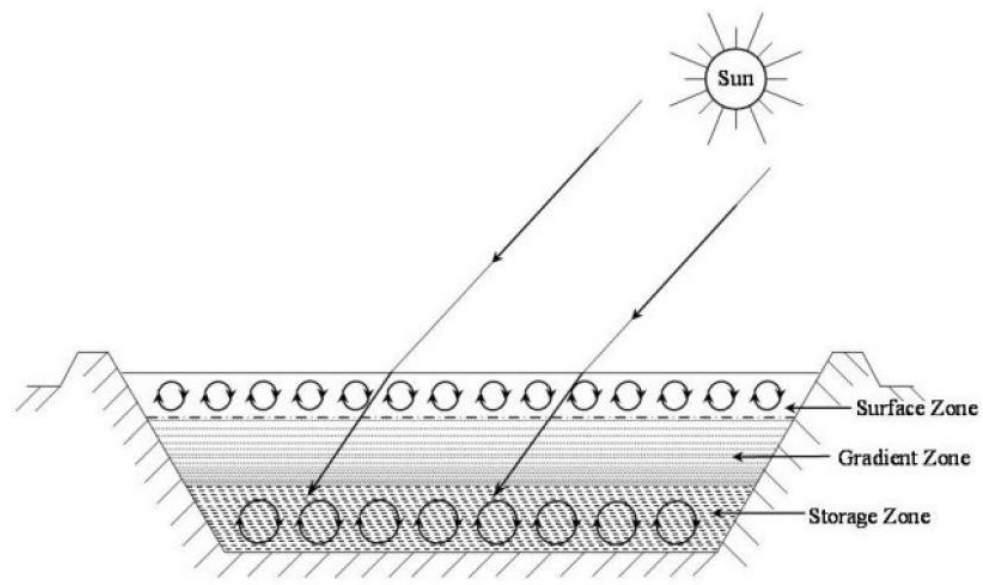

Fig. 1. Theschematic representation of salinitygradient solar pond[1].

\subsection{Land}

\section{Designs}

Salinity gradient solar ponds become more economical when their sizes are approximately 10,000 to $100,000 \mathrm{~m}^{2}$. The feasibility of the Land/Site depends on various factors which can be summarized as, having flat Land to minimize earth moving requirements. Dry Soil for good thermal insulation.

All these conditions are related to each other in some way or another and we have to compromise on some of the conditions and look for a site with minimum losses for instance a high solar radiation means high evaporation losses.

Therefore, we have chosen Cairo in Egypt which has a flat land and the soil is feasible for constructing a solar pond. And our site is near the River Nile in the out skirts of Cairo. The solar pond area is $100 \times 100 \mathrm{~m}$. The thickness of the surface zone, gradient zone and storage zone are $0.3,1.0$ and $1.5 \mathrm{~m}$ respectively. The pond shape is square.

\subsection{Insulation}

The bottom of the pond isinsulated with sheets of polystyrene. For choosing the insulation material following properties should be observed:

It should withstand the maximum temperature anticipated in the pond.

It should be resistant to ultraviolet radiations.

It should not react with the salt.

\subsection{Salt-Water Sources}

Sodium chloride $(\mathrm{NaCl})$ will be used. The aqueous solutions of $\mathrm{NaCl}$ can attain maximum density of $1200 \mathrm{~kg} / \mathrm{m}^{3}[1]$

\subsection{Water sources}

Sodium chloride $(\mathrm{NaCl})$ will be used. The aqueous solutions of $\mathrm{NaCI}$ can attain maximum density of $1200 \mathrm{~kg} / \mathrm{m}^{3}[1]$.

Availability of fresh water with low salinity is one of the most important features of a solar pond. So that the amount of salt may be added according to the application for which the solar pond is being designed [1]. 


\subsection{Location}

The task was to design a solar pond in Africa however, Cairo in Egypt has been chosen as a case study due to various reasons such as annual solar radiation, availability of land, economically a stable country as compared to rest of Africa.

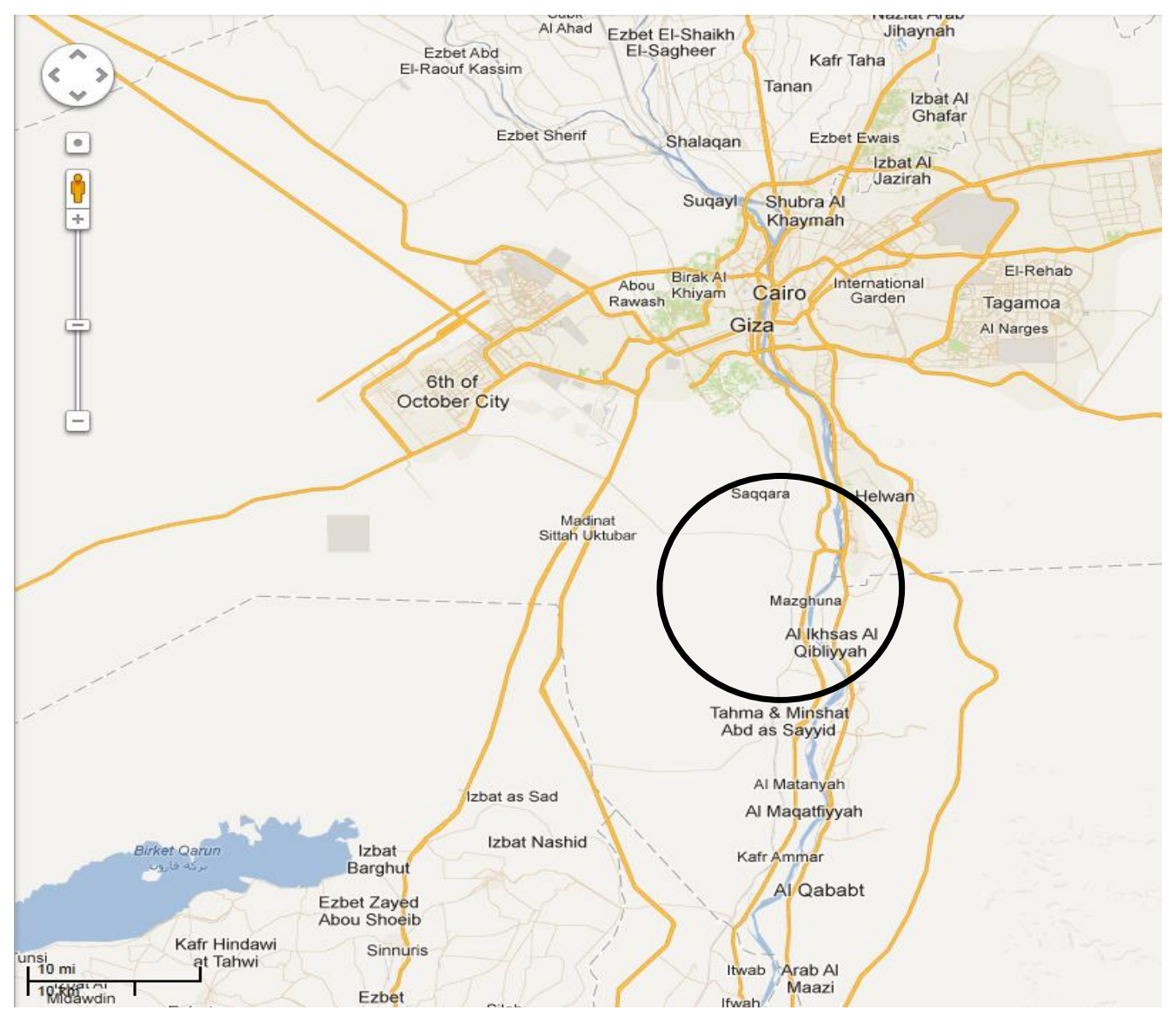

\section{Mathematical Models}

The efficiency of a solar pond depends upon the incident sun light on the water surface and the amounts of heat lost and gained during this process can be formulized mathematically. As we know we consider three layers in a solar pond with different densities and that has already been defined in the introduction part. The energy balance equations can be derived of the thin upper convecting layer which is the least denser and the lower storage Zone layer which has the highest concentration of salt and is the most dense layer trapping the heat inside it.

\subsection{The Steady State Model for Upper Zone}

Heat losses are the most important factor for solar pond in term of performance. The heat losses can be included convective loss, radiation loss,evaporation and side losses as shows in 'Fig." 2.

Keeping in view the different heat losses and gains the energy balance equation for the upper layer can be written as:

$\rho_{u} C_{p u} A x_{u} \frac{d T}{d t}=Q_{s r u}+Q_{u b}-Q_{u c}-Q_{u r}-Q_{u e}[4](1)$

Where:

$\rho_{u}=$ Density of water $\left(\mathrm{kg} / \mathrm{m}^{3}\right)$

$C_{p u}=$ Specific heat of water $\left(\mathrm{J} / \mathrm{kg}^{\circ} \mathrm{C}\right)$

$A=$ Surface area of the Pond $\left(\mathrm{m}^{2}\right)$

$x_{u}=$ Thickness of the layer $(\mathrm{m})$

$Q_{\text {sru }}=$ Absorbed heat of solar radiation in the upper zone $\left(\mathrm{W} / \mathrm{m}^{2}\right)$

$Q_{u b}=$ Heat gained from bottom in the upper zone $\left(\mathrm{W} / \mathrm{m}^{2}\right)$

$Q_{u c}=$ Heat loss by convection in the upper zone $\left(\mathrm{W} / \mathrm{m}^{2}\right)$

$Q_{u r}=$ Heat loss by radiation in the upper zone $\left(\mathrm{W} / \mathrm{m}^{2}\right)$ 
$Q_{u e}=$ Heat loss by evaporation in the upper zone $\left(\mathrm{W} / \mathrm{m}^{2}\right)$

$Q_{u w}=$ Heat loss from the sides in the upper zone $\left(\mathrm{W} / \mathrm{m}^{2}\right)$

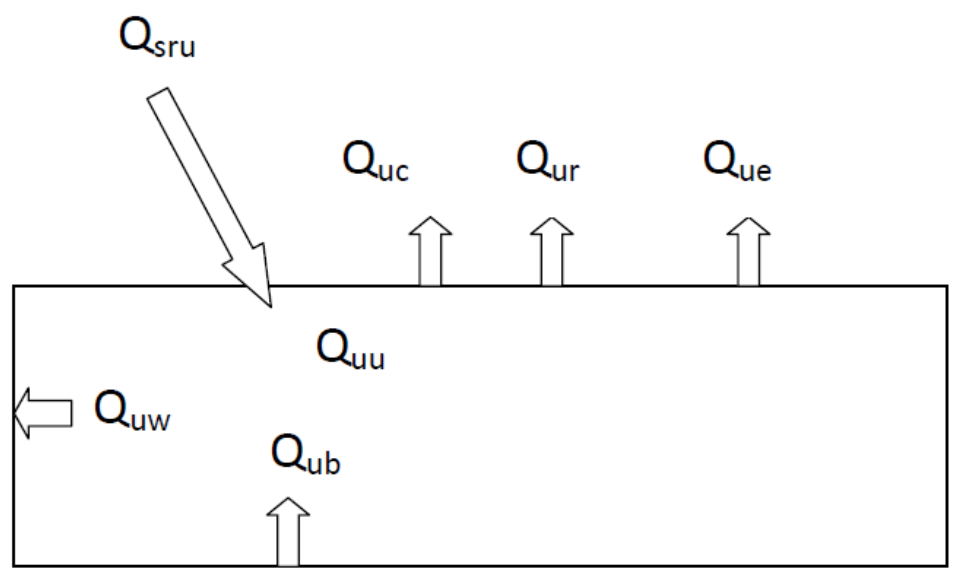

Fig.2.Heat balance in the Upper zone [4].

\subsection{Absorbed Heat in the Upper Layer from Solar Radiation, $\mathbf{Q}_{\text {sru }}$}

The amount of absorbed solar radiation in the upper zone of a pond can be estimated according to the amount of the solar beam attenuation at depth $\mathrm{x}$.

$Q_{\text {srui }}=\tau A R(2)$

$Q_{\text {sruo }}=\tau A_{u} R \sum_{n=1}^{4} \eta_{n} e^{-\mu_{n} x_{u} / \cos r}(3)$

$Q_{\text {sru }}=Q_{\text {srui }}-Q_{\text {sruo }}(4)$

Where:

$Q_{\text {srui }}=$ Input solar radiation to the upper zone

$Q_{\text {sruo }}=$ Output solar radiation from the upper zone at depth x

$Q_{\text {sru }}=$ Absorbed solar radiation within the upper zone

$\tau=$ Transmissivity of water

$A=$ Pond surface area

$A_{u}=$ Lower surface area of the upper area

The transmissivity of water can be written as:

$\tau=2 N \cos \theta \cos r\left(c^{2}+d^{2}\right)(5)$

Where:

And:

$$
c=\frac{1}{(\cos r+N \cos \theta)}
$$

$d=\frac{1}{(\cos \theta+N \cos r)}(6)$

4.3Convection Heat Loss, $\mathrm{Q}_{\mathrm{uc}}$

The convection heat loss from the upper layer zone is affected by wind speed and temperature difference between the atmosphere and the water surface. The heat will be lost from the upper layer into atmosphere. The equation can be written as:

$Q_{u c}=h_{c} A_{u}\left(T_{u}-T_{a} 7\right)(7)$

Where:

$h_{c}=$ Convection heat transfer coefficient $\left(\mathrm{W} / \mathrm{m}^{20} \mathrm{C}\right)$

$A_{u}=$ Upper layer surface area $\left(\mathrm{m}^{2}\right)$

$T_{u}=$ Upper layer temperature $\left({ }^{\circ} \mathrm{C}\right)$

$T_{a}=$ Ambient air temperature $\left({ }^{\circ} \mathrm{C}\right)$

The convection heat transfer coefficient equation can be written as:

$$
h_{c}=5.7+3.8 v
$$

Where:

$v=$ Wind speed $(\mathrm{m} / \mathrm{s})$ 
4.4Radiation Heat Loss, Qur

The solar pond acts as a black body radiator which it will transfer the heat by radiation. The main factors of transferring the heat into sky are the ambient, water temperatures and the upper layer area. Therefore, the equation can be written as:

$Q_{u r}=\sigma E_{s} A_{u}\left[\left(T_{u}\right)^{4}-\left(T_{k}\right)^{4}\right](8)$

Where:

$\sigma=$ Boltzman-Stefan constant $\left(\mathrm{W} / \mathrm{m}^{2} \mathrm{~K}^{4}\right)=5.6704 \times 10^{-8} \mathrm{~W} / \mathrm{m}^{2} K^{4}$

$E_{s}=$ Emissivity of the water surface

$A_{u}=$ Upper layer area $\left(\mathrm{m}^{2}\right)$

$T_{u}=$ The upper layer temperature $(\mathrm{K})$

$T_{k}=$ The sky temperature $(\mathrm{K})$

The sky temperature equation can be written as:

Where:

$$
T_{k}=0.0552\left(T_{a}\right)^{1.5}
$$

$T_{a}=$ Ambient air temperature $(\mathrm{K})$

4.5Evaporation Heat Loss, $\left(\mathrm{Q}_{\mathrm{ue}}\right)$

The evaporation heat loss is considered to be the largest heat loss from the upper layer zone. The equation can be written as:

$Q_{u e}=\left(\frac{\lambda h_{c}}{1.6 C_{a} P_{a t m}}\right)\left(P_{u}-P_{a}\right)(9)$

Where:

$\lambda=$ Water evaporation latent heat $(\mathrm{kJ} / \mathrm{kg})$

$C_{a}=$ Humid heat capacity of air $\left(\mathrm{kJ} / \mathrm{kg}{ }^{\circ} \mathrm{C}\right)$

$P_{\text {atm }}=$ Atmospheric pressure $(\mathrm{mmHg})$

$P_{u}=$ Water vapour pressure as at the upper layer temperature $(\mathrm{mmHg})$

$P_{a}=$ Water vapour partial pressure in the ambient temperature $(\mathrm{mmHg})$

$h_{c}=$ Convection heat transfer coefficient $\left(\mathrm{W} / \mathrm{m}^{2 \mathrm{o}} \mathrm{C}\right)$

Where the water vapour pressure as at the upper layer temperature can be defined by:

$P_{u}=\exp \left(18.403-\frac{3885}{T_{u}-230}\right)(10)$

Where:

$T_{u}=$ Upper layer temperature $\left({ }^{\circ} \mathrm{C}\right)$

The water vapour partial pressure in the ambient temperature can be defined by:

Where:

$$
P_{a}=\left(\gamma_{h}\right) \exp \left(18.403-\frac{3885}{T_{a}-230}\right)
$$

$\gamma_{h}=$ Relative humidity

$T_{a}=$ Ambient air temperature $\left({ }^{\circ} \mathrm{C}\right)$

4.5 Inlet Heat Flux in the Upper Zone, $\mathrm{Qub}_{\mathrm{ub}}$

The inlet heat flux to the upper zone can be assumed to be the same as outlet heat flux $\left(\mathrm{Q}_{\mathrm{st}}\right)$ in the lower zone when the steady state as an assumption. So equation can be written as:

$Q_{s t}=Q_{u b}=U_{t} A\left[T_{s}-T_{u}\right](11)$

Where:

The resistances values are:

$$
U_{t}=\frac{1}{R_{3}+R_{c}+R_{2}}
$$

$R_{3}=\frac{1}{h_{3}}$

$R_{c}=\frac{x_{g r}}{K_{w}}$

$R_{2}=\frac{1}{h_{2}}$

Where:

$U_{t}=$ Heat transfer coefficient towards the top of the pond $\left(\mathrm{W} / \mathrm{m}^{2 \circ} \mathrm{C}\right)$

$A=$ Surface area of the pond $\left(\mathrm{m}^{2}\right)$

$T_{s}=$ Storage zone temperature $\left({ }^{\circ} \mathrm{C}\right)$

$T_{u}=$ Upper zone temperature $\left({ }^{\circ} \mathrm{C}\right)$

$x_{g r}=$ Gradient zone thickness $(\mathrm{m})$

$K_{w}=$ Thermal conductivity of water $\left(\mathrm{W} / \mathrm{m}^{20} \mathrm{C}\right)$

$h_{3}=$ Convective heat transfer coefficient at the boundary between the lower and the gradient zones $\left(\mathrm{W} / \mathrm{m}^{2 \circ} \mathrm{C}\right)$ 
$h_{2}=$ Convective heat transfer coefficient at the boundary between the upper and the gradient zones $\left(\mathrm{W} / \mathrm{m}^{2 \circ} \mathrm{C}\right)$ 4.6 Heat loss from the sides

The heat loss from the sides can be neglected, especially for large ponds. Also the good insulation materials will be installed. Therefore:

$Q_{u w}=0(12)$

\section{The Steady State Model for Storage Zone}

The heat losses in the storage zone are less and can be more controlled that the upper zone as all type of heat losses show in Figure 3. The heat losses that occur in the storage zone are mainly from conduction heat transfer. The appropriate insulation can be used for sides and bottom of the storage zone to improve the performance of the storage zone. Also the gradient zone can affect the performance by obstructing the upward heat loss from the storage zone to the upper zone. The steady state of model of storage zone can be written as:

$\rho_{s} C_{p s} A x_{s} \frac{d T}{d t}=Q_{s r s}-Q_{s t}-Q_{s b}-Q_{s w}-Q_{s e}(13)$

Where:

$\rho_{s}=$ Density of Water

$C_{p s}=$ Specific heat of water

$A=$ Surface Area of the Pond

$x_{s}=$ Thickness of the layer

$Q_{s r s}=$ Absorbed heat of solar radiation in the storage zone $\left(\mathrm{W} / \mathrm{m}^{2}\right)$

$Q_{s t}=$ Heat loss from the top in the storage zone $\left(\mathrm{W} / \mathrm{m}^{2}\right)$

$Q_{s b}=$ Heat loss from the bottom in the storage zone $\left(\mathrm{W} / \mathrm{m}^{2}\right)$

$Q_{s w}=$ Heat loss from the side in the storage zone $\left(\mathrm{W} / \mathrm{m}^{2}\right)$

$Q_{s e}=$ Heat loss by heat extraction in the storage zone $\left(\mathrm{W} / \mathrm{m}^{2}\right)$

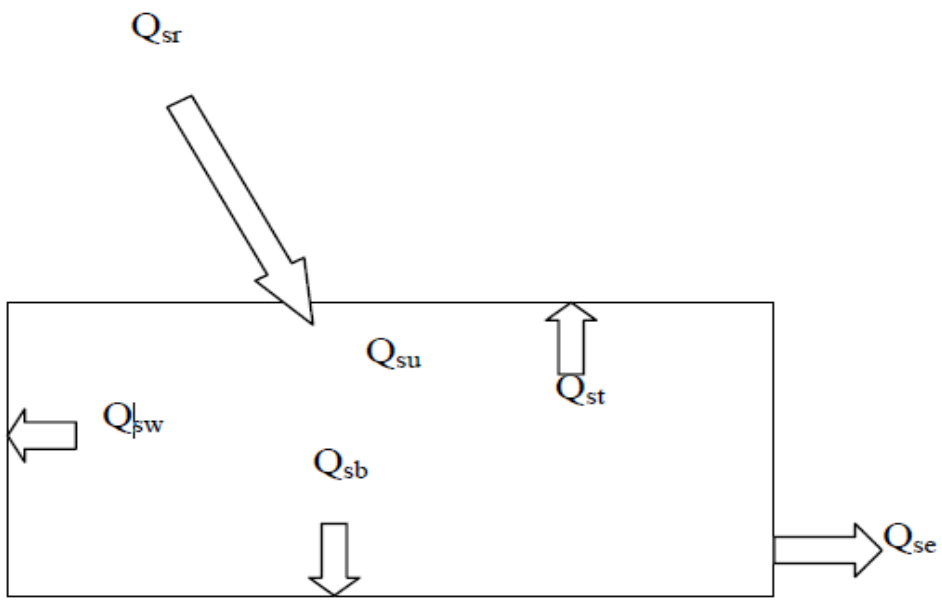

Fig.3.Theheat balance in the storage zone[4].

\subsection{Absorbed heat of solar radiation in the storage zone}

The amount of absorbed solar radiation in the upper zone of a pond can be estimated according to the amount of the solar beam attenuation at depth $\mathrm{x}$ of the storage zone. The equation would be the same as the absorbed heat of solar radiation in the upper zone as mentioned earlier.

5.2 Sides and Heat Extraction Losses, $\mathrm{Q}_{\mathrm{sw}}$ and $\mathrm{Q}_{\mathrm{se}}$

The storage zone causes the major heat losses through the sides of this zone. The amount of heat losses is mainly depending on the solar pond area. Therefore, the sides of this solar pond has decided to be insulated which these heat losses can be neglected. So it is assumed that solar pond is in warming-up status, therefore, the heat extraction assumed to be zero. Thus:

$Q_{s e}=09(14)$

$$
Q_{s w}=0
$$

5.3 Bottom Losses, $\mathrm{Q}_{\mathrm{sb}}$

The heat losses at the bottom are also the major heat losses in this zone. It is also depended on the solar pond area which large solar pond is likely to lose more heat than the small solar pond. The distance between the bottom of solar pond and underground water table could affect the heat loss from the bottom, as more heat 
exchange occurs when the distance between underground water table and the storage zone is short. So the equation of heat loss from the bottom can be written as:

$Q_{s b}=U_{b} A\left[T_{s}-T_{g}\right](15)$

Where:

The resistances values are:

$$
U_{b}=\frac{1}{R_{4}+R_{g}+R_{5}}
$$

$R_{4}=\frac{1}{h_{4}}$

$R_{g}=\frac{x_{g}}{K_{g}}$

$R_{5}=\frac{1}{h_{5}}$

Where:

$U_{g}=$ Heat transfer coefficient towards the top of the pond $\left(\mathrm{W} / \mathrm{m}^{2 \circ} \mathrm{C}\right)$

$A=$ Surface area of the pond $\left(\mathrm{m}^{2}\right)$

$T_{S}=$ Storage zone temperature $\left({ }^{\circ} \mathrm{C}\right)$

$T_{g}=$ Ground sinks temperature $\left({ }^{\circ} \mathrm{C}\right)$

$x_{g}=$ The depth of ground sink zone $(\mathrm{m})$

$K_{g}=$ Thermal conductivity of water $\left(\mathrm{W} / \mathrm{m}^{20} \mathrm{C}\right)$

$h_{4}=$ Convective heat transfer coefficient at the boundary between the storage zone and the surface of the bottom $\left(\mathrm{W} / \mathrm{m}^{20} \mathrm{C}\right)$

$h_{5}=$ Convective heat transfer coefficient at the surface of the ground water sink $\left(\mathrm{W} / \mathrm{m}^{2 \circ} \mathrm{C}\right)$

5.4 Outlet Heat Flux in the Storage Zone, $\mathrm{Q}_{\mathrm{st}}$

As mentioned early, in the steady state assumption. The outlet heat flux would be equalled to the inlet heat flux, therefore:

$Q_{s t}=Q_{u b}=U_{t} A\left[T_{s}-T_{u}\right](16)$

5.5 The Steady State Model for Gradient Zone

In steady state the gradient zone is being considered to maintain the temperature in the non convecting layer and it can be considered a slab between the upper and the lower layer as the input heat and the output heat of this Zone are equal.

Table 1: The values of parameters of Cairo [6]

\begin{tabular}{|l|l|l|l|l|l|l|}
\hline Month & $\begin{array}{l}\text { Air } \\
\text { temperature } \\
\left({ }^{\circ} \mathrm{C}\right)\end{array}$ & $\begin{array}{l}\text { Relative } \\
\text { humidity }(\%)\end{array}$ & $\begin{array}{l}\text { Daily solar radiation } \\
\text { horizontal } \\
\left.\mathrm{kWh} / \mathrm{m}^{2} / \text { day }\right)\end{array}$ & $\begin{array}{l}\text { Atmospheric } \\
\text { pressure }(\mathrm{kPa})\end{array}$ & $\begin{array}{l}\text { Earth } \\
\text { temperature } \\
\left({ }^{\circ} \mathrm{C}\right)\end{array}$ & $\begin{array}{l}\text { Wind } \\
\text { speed } \\
(\mathrm{m} / \mathrm{s})\end{array}$ \\
\hline January & 13.3 & 56.5 & 3.23 & 100 & 14.1 & 4.74 \\
\hline February & 13.6 & 53.7 & 3.91 & 100 & 15.1 & 5.01 \\
\hline March & 16.0 & 52.5 & 5.11 & 100 & 18.7 & 4.99 \\
\hline April & 20.1 & 44.8 & 6.28 & 100 & 24.1 & 4.78 \\
\hline May & 23.4 & 43.8 & 6.99 & 100 & 28.5 & 4.80 \\
\hline June & 26.3 & 44.7 & 7.69 & 99.8 & 31.9 & 4.68 \\
\hline July & 28.2 & 45.0 & 7.33 & 99.5 & 33.8 & 4.73 \\
\hline August & 28.2 & 47.6 & 6.85 & 99.6 & 33.5 & 4.71 \\
\hline September & 26.3 & 51.5 & 5.86 & 99.9 & 31 & 4.78 \\
\hline October & 22.8 & 57.8 & 4.48 & 100 & 26.1 & 4.68 \\
\hline November & 18.9 & 56.3 & 3.45 & 100 & 20.6 & 4.44 \\
\hline December & 14.8 & 55.9 & 3.00 & 100 & 15.6 & 4.71 \\
\hline Annual & 21.0 & 50.8 & 5.35 & 100 & 24.5 & 4.75 \\
\hline
\end{tabular}

The equations from previous chapter are for determining the storage zone temperature during different months of a year. Due to computational complexities, time constraints and limited literature availability for solar ponds, the existing solar pond in Riyadh, Saudi Arabia has been chosen for comparing the solar radiation due to this region has similarity of the values ofparameters toCairo, Egypt which is shown in "Table" 2 from NASA website and the irradiation plot in "Fig." 4. 


\begin{tabular}{|l|l|l|}
\hline Month & $\begin{array}{l}\text { Cairo Radiation } \\
\left(\mathrm{MJ} / \mathrm{m}^{2} / \text { day }\right)\end{array}$ & $\begin{array}{l}\text { Riyadh Radiation } \\
\left(\mathrm{MJ} / \mathrm{m}^{2} / \text { day }\right)\end{array}$ \\
\hline January & 11.628 & 13.536 \\
\hline February & 14.076 & 16.668 \\
\hline March & 18.396 & 19.368 \\
\hline April & 22.608 & 22.284 \\
\hline May & 25.164 & 25.74 \\
\hline June & 27.684 & 28.332 \\
\hline July & 26.388 & 27.324 \\
\hline August & 24.66 & 25.74 \\
\hline September & 21.096 & 22.824 \\
\hline October & 16.128 & 19.692 \\
\hline November & 12.42 & 15.192 \\
\hline December & 10.8 & 12.672 \\
\hline Annual & 19.26 & 20.772 \\
\hline
\end{tabular}

Table 2: Irradiation data bewtween Cairo and Riyadh [6].

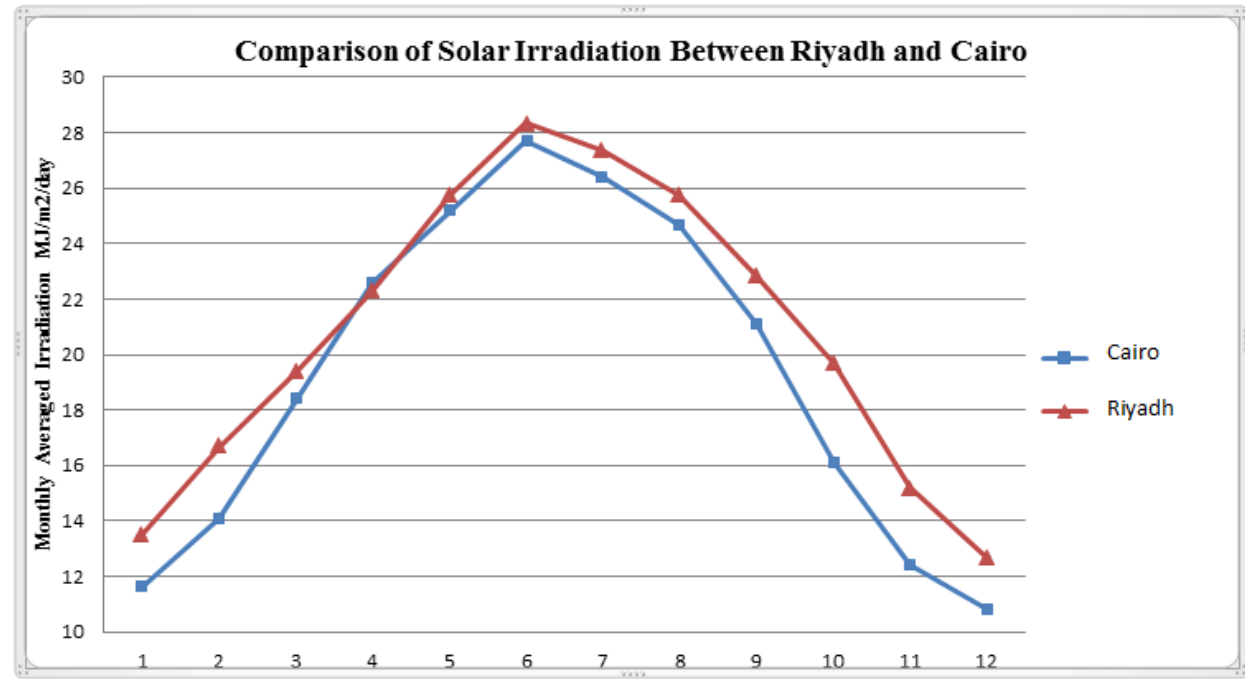

Fig.4.The plot of Riyadh and Cairo irradiation data [6].

In"fig" 5 shows the temperature in the Storage Zone during a year which is the maximum during June-August when the summer heat is the most in these regions and the maximum temperature attained is more than 75 Degree Celsius.

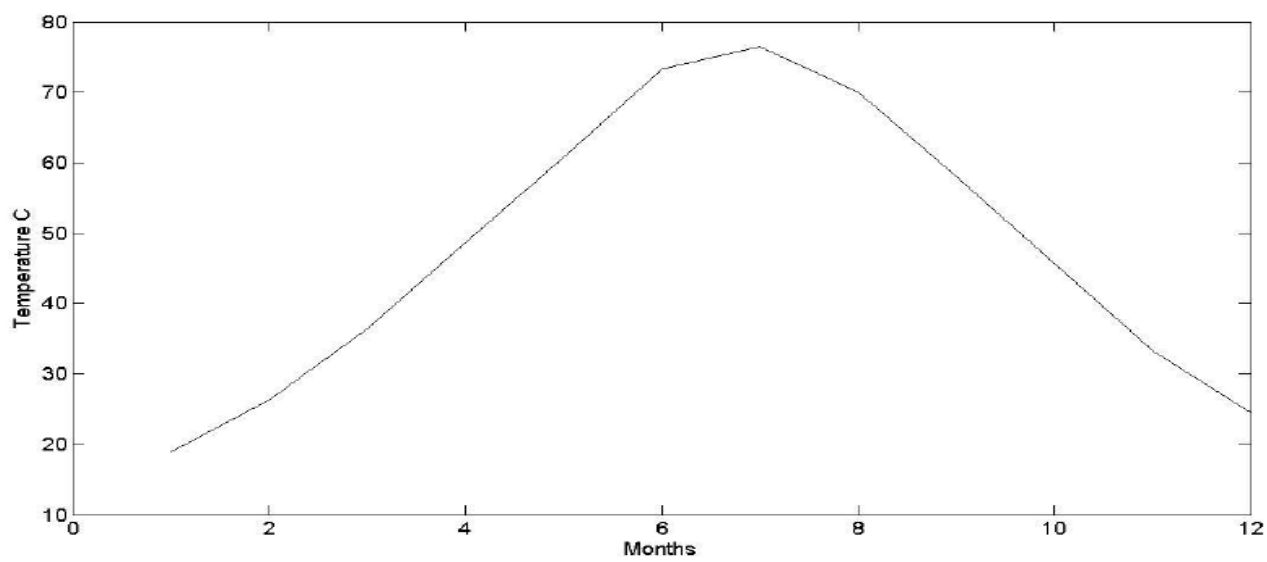

Fig.5. Thestorage zone temperature during the12 months in Riyadh[4]. 
Similarly the results from Kuwait City Solar Pond are almost the same as the region shares almost the same amount of sun radiation as shows in "Fig." 6.

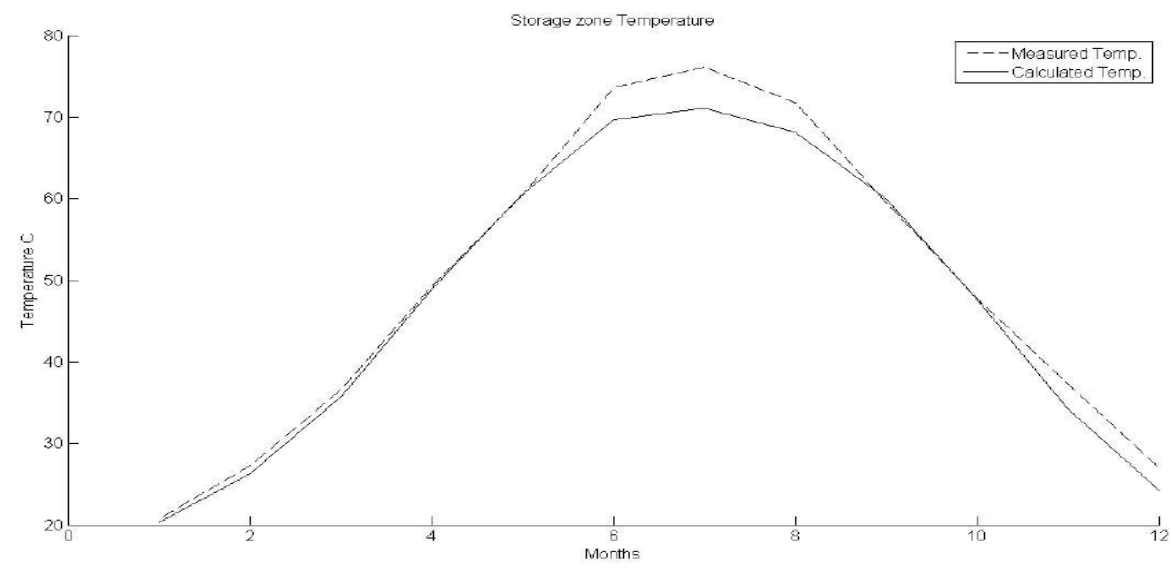

Fig.6.Storage zone temperature during 12 months in Kuwait City[4]

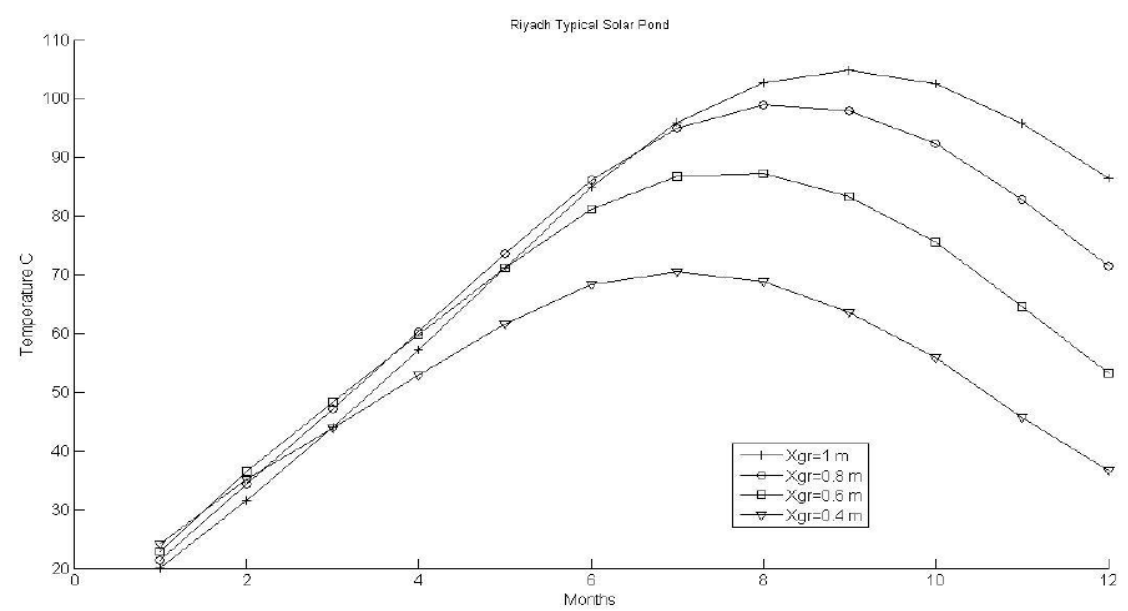

Fig.7. The storage zone temperature for different depths of the gradient layer [4].

The above graph shows the effect of different gradient zone depths on the storage zone temperature. The different depths used for gradient zone are $0.4 \mathrm{~m}, 0.6 \mathrm{~m}, 0.8 \mathrm{~m} \& 1 \mathrm{~m}$ respectively. In the first month the temperature drops as we increase the depth of the gradient which is due decreased solar radiation reaching the storage zone directly. But from $2^{\text {nd }}$ month until the $6^{\text {th }}$ month the temperature curves are getting more clear with $1 \mathrm{~m}$ deep gradient zone showing an increasing trend and after 6 months the temperature of the storage zone rises up to 105 Degree Celsius with $1 \mathrm{~m}$ deep Gradient zone because more and more heat is collected and conducted through gradient zone into the storage zone. So $1 \mathrm{~m}$ is the optimum thickness of the gradient zone as increasing the thickness more will decrease the temperature as more and more solar radiation will be absorbed by the gradient zone and keeping the gradient layer thin would mean more loss of heat from the storage zone through conduction.

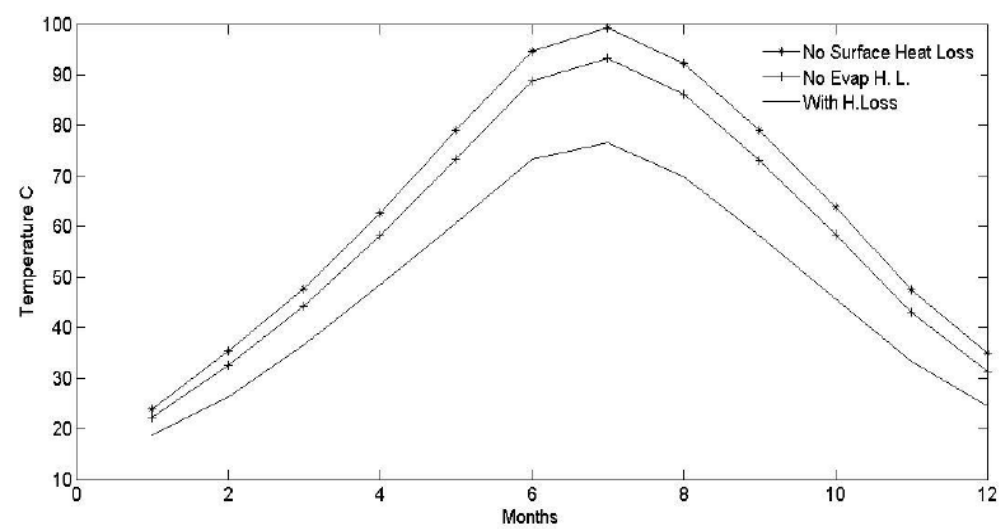

Fig.8.The effect of evaporation heat loss and covering the pond [4]. 
Temperature has an interesting effect on the storage zone temperature of the solar pond. The temperature of the storage zone should increase with the increase in the surrounding temperature but losses due to evaporation, radiation, conduction and convection decreases the storage zone temperature. Solar pond has a heat loss due to evaporation in increasing temperatures which can be reduced by covering the solar pond. The above graph clearly shows an increase in the storage zone temperature after covering the solar pond.

Increasing the thickness of the top insulation increases the storage zone temperature. It can be analyzed from the graph that the heat loss reduces a lot by increasing the thickness upto $40 \mathrm{~cm}$. Some studies suggest that the heat losses are reduced by $55 \%$ with $10 \mathrm{~cm}$ thickness of insulation and the thickness from $20-40 \mathrm{~cm}$ reduces the heat losses further upto $6 \%$ and the stored energy is increased by $15 \%$. Further increasing the thickness of insulation has no effect on the heat loss and the stored energy.

\subsection{Effect of Radiation}

Radiation has direct effect on the temperature of the storage zone in the solar pond but it mainly depends upon the thickness of the gradient layer for instance at $1 \mathrm{~m}$ depth $36 \%$ of the radiation entering the pond is available and at $2 \mathrm{~m}$ it reduces to $30 \%$. Increased radiation will increase the temperature as more heat will be absorbed as mentioned before depth of the pond is an important factor in that along with the evaporation losses which can be reduced by introducing a cover on the pond.

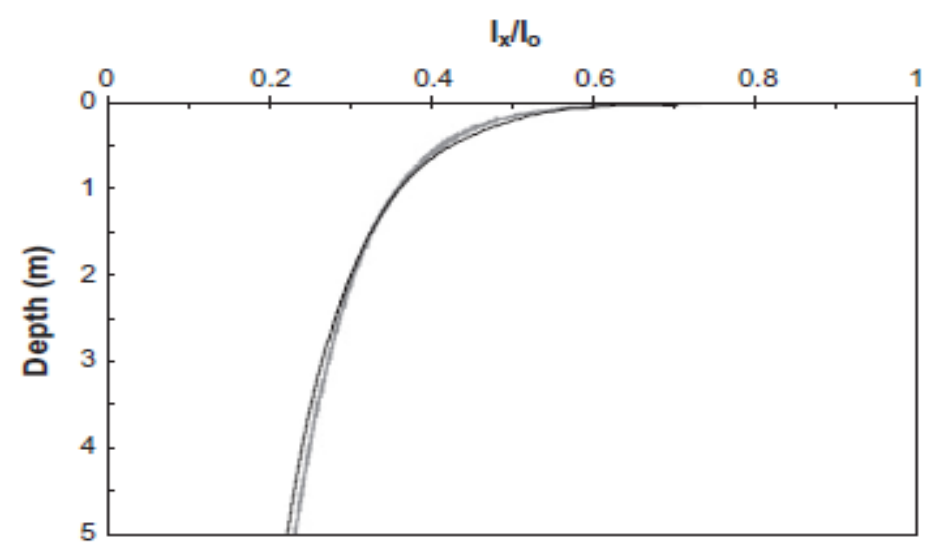

\subsection{Effect of Density}

By increasing the density of the storage layer by increasing the salt concentration will increase the temperature as more and more heat will be trapped but the problem with increasing the salt concentration is that there will be more and more salt flushing in the upper layers and the density of the upper layers will increase and the temperature in the lower layer will decrease and there will be more need of maintenance by removing the salted water from the upper layer so the maximum density of the $\mathrm{NaCl}$ aqueous solution in the lower layer is $1200 \mathrm{~kg} / \mathrm{m}^{3}$.

\subsection{Cost Estimation}

The essential costs for construction of solar ponds are listed below. All costs have been converted from Egypt currency into Great British Pounds.

\subsubsection{Steels}

The reinforced steels use for the construction estimated around 3050 tonnes. The total costs are approximately $£ 150,000$ including the labour cost.

\subsubsection{Concretes}

The concrete slabs thickness of $0.3 \mathrm{~m}$ been designed to be the foundation of solar ponds.

Therefore, the total volume of concretes used approximately $3000 \mathrm{~m}^{3}$. The total costs was put at $£ 173,000$ including the labour cost.

\subsubsection{Excavation}

The excavation must be done in order to construct the solar pond which the area of $10000 \mathrm{~m}^{2}$ and $3 \mathrm{~m}$ depth would be dug. The total costs would be around $£ 50,000$ including the labour costs and machinery costs. Thickness of side walls was $0.3 \mathrm{~m}$ and the total area of $1200 \mathrm{~m}^{2}$. 
Design of Solar Pond calculation and technique in Africa

\begin{tabular}{|l|l|}
\hline Category & Cost,£ \\
\hline Steels & $£ 150,000$ \\
\hline Excavations & $£ 50,000$ \\
\hline Side walls & $£ 33,000-40,000$ \\
\hline Lands & $£ 1,150,000-1,300,000$ \\
\hline Paints & $£ 18,000$ \\
\hline Others costs & $£ 25,000$ \\
\hline Total & $£ 1,599,000-1,756,000$ \\
\hline
\end{tabular}

Table 3: Total costs of a solar pond

\section{Conclusion}

Solar Pond is the most cost effective renewable technology with so many practical applications. The Solar Pond designed in this coursework can be used for different applications such as desalination of water as source of clean water especially in countries likes Sudan, Mali and others places in Africa that are facing chronic water situation, providing hot water for domestic use, hot water industrial use and importantly it can be used to produce electricity. Solar pond has some hazards which can be monitored successfully. During the hot periods others wise called Dry Season in Africa, the temperature of the storage zone can rise up to 100degree Celsius so safety signs and fence around the pond are placed to secure the safety of the locals and monitoring team. The monitoring team has to monitor the amount of the salt flushing upwards as the upper layer would need cleaning and filling again with fresh water due to loss by evaporation.The depths of different layers depend upon the optimum temperatures even rising up to100 degree Celsius or more. Solar Ponds can be a success story in the third world countries of Africa with little or no resources. Solar ponds on smaller scales for providing hot water for small villages can be very useful as it can save cuttings of precious forests in the Africa countries. Dependence on burning fossils fuels and woods in households is affecting the environment and global warming phenomenon so the need of hour is to introduce these cleaner technologies like solar pond heating systems throughout the world as on smaller and larger scales. The advantage of solar pond technology over other renewable energies is that this technique is cost effective and simple. But still more research is needed to make this technique more efficient and effective

\section{References}

[1] Akbarzadeh, A., Golding, P. andAndrews, A., Solar Pond: Solar Energy Conversion and Photoenergy Systems Vol. I, [pdf], Availableat : $<$ http://www.eolss.net/Sample-Chapters/C08/E6-106-08.pdf > [Accessed 19 December 2012]

[2] Boyle, G., 1996.Renewable Energy power for a Sustainable Future. Oxford, Oxford University Press.

[3] Sayigh, A., 1977. Solar Energy Engineering, London, Academic Press

[4] Alenezi, I., 2012. Theoretical Modelingof Salinity Gradient Solar Pond in Saudi Arabia .Ph. D. University of Surrey.

[5] Sharif, A., Hussaini, H. and Alenezi, I., 2011. New method for predicting the performance of Solar Pond in any Sunny Part of the WorldLinkoping, Sweden 8-13 May 2011. Surrey: United Kingdom.

[6] NASA, 2013. NASA Surface Meteorology and Solar Energy[Online] Available at:<http://eosweb.larc.nasa.gov/cgibin/sse/grid.cgi? \&num=212121\&lat=30.057\&submit=Submit\&hgt=100\&veg=17\&sitelev=\&email=w_wongsakorn@hotmail.com\& $\mathrm{p}=$ grid_id $\& \mathrm{p}=$ swvdwncook\&p=swv_dwn\&p=T10M\&p=TSKIN\&p=wspd50m\&p=RH10M\&p=PS\&step=2\&lon=31.226>

[7] Anderson, C. G. (1959). Limnology of a Shallow Saline Meromitic Lake, Limnology and OceanographyNo.3, pp.259-269

[8] Wilson, A. T. and Well Mann.H.,1962.Lake Anda.anAntartic Lake,Nature,No.96,pp.1171-1173.

[9] Tundee,S., Terdtoon, P.,Sakulchangsatjatai,P.,Singh,R.\&Akbarzaded,A.,2010.Heat Extraction from Salinity-Gradient SolarPonds Using Heat Pipe Heat Exchanger,[online] Available at:http://www.sciencedirect.com/science/article/pii/S0038092x10001568\#

[10] German,M.A \&Muntasser M.A.,2007.Sizing and Thermal Study of SalinityGradient Solar Ponds Connecting with The MED Desalination Unit,[online] Available at:http://www.sciencedirect.com/science/article/pii/S001191640708264

[11] Saxena, A., K., Sugandhi, S.and Husain, M.2008.Significant Depth of Ground Water Table for Thermal Performance of Salt Gradient Solar Pond, [online] Available at:http://wwwtopices.nytimes.com/top/news/science/article/pii/S0960148001663

[12] Al-Dabbas, M. A., 2011. Optimum Salt Gradient Solar Pond IN Jordan,[online]Available at <http://www.epa.gov/climatechange/ghgemissions/global.html> [Accessed 7January 2013].

[14] EPA United States Environmental ProtectionAgency, 2012.Global http://www.epa.gov/climatechange/ghgemissions/global.html [Accessed7 January, 2013].

[15] Jha, A., 2011.Wind Turbine Technology. [E-book] London:CRC Press.Available through:University Surrey library website http://wwwprism.talis.com/surrey-ac/ [Accessed 7 January,2013].

[16] Vouloudis, A., 2010.Technical review of design requirements of wind energy conversion systems and analysis of targets set and progress achieved in Greece and UK. MSc.University of Surrey.

[17] Pearce, F.2006.Introduction: Climate Change, New Scientist, [online] Available at:http://www.newscientist.com/article/dn9903intant-expert-climate-change.html[Accessed 7 January, 2013.]. 